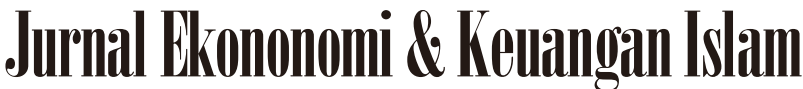

\author{
Available at http://journal.uii.ac.id/index.php/jeki
}

\section{Studi komparatif tingkat efisiensi perbankan konvensional dan perbankan syariah di Indonesia}

\author{
Nur Hidayah \\ Universitas Trisakti, Jakarta \\ e-mail: dayhikaru@gmail.com
}

\begin{tabular}{l} 
Keywords: \\
Efficiency, Conventional \\
banking, Sharia banking \\
\hline DOI: \\
10.20885/JEKI.vol2.iss2.art4
\end{tabular}

10.20885/JEKI.vol2.iss2.art4

\begin{abstract}
This study aims to analyze and compare the level of efficiency of conventional banks and sharia banks in Indonesia during 2012 to 2013. Samples in this study were taken randomly with the formula slovin which then obtained a sample of 49 banks consisting of 11 sharia banks and 38 conventional banks. This study uses secondary data that can be taken from the financial statements of bank publications. Selection of variables used is chosen based on intermediation approach which is the main function of banking. Data Envelopment Analysis (DEA) method is used to analyze data in this research with approach of Constant Return to Scale (CRS) and input oriented. In this study also used the Mann-Whitney Test to determine whether or not the difference in efficiency between conventional banks and sharia banks in Indonesia during the study period. Based on the calculation of DEA, there are 3 banks that experienced perfect efficiency during the study period. From the MannWhitney test results revealed that there is a significant difference in the efficiency of conventional banking and sharia banking in Indonesia during the first quarter of 2012 until the third quarter of 2013.
\end{abstract}

\begin{abstract}
Abstrak
Penelitian ini bertujuan untuk menganalisis dan membandingkan tingkat efisiensi bank konvensional dan bank syariah di Indonesia selama 2012 hingga 2013. Sampel dalam penelitian ini diambil secara random dengan rumus slovin yang kemudian didapat sampel sebanyak 49 bank yang terdiri dari 11 bank syariah dan 38 bank konvensional. Penelitian ini menggunakan data sekunder yang dapat diambil dari laporan keuangan publikasi bank. Pemilihan variabel yang digunakan dipilih berdasarkan pendekatan intermediasi yang merupakan fungsi pokok perbankan. Metode Data Envelopment Analysis (DEA) digunakan untuk menganalisis data dalam penelitian ini dengan pendekatan Constant Return to Scale (CRS) dan input oriented. Dalam penelitian ini juga menggunakan Uji Mann-Whitney untuk mengetahui ada atau tidaknya perbedaan tingkat efisiensi antara bank konvensional dan bank syariah di Indonesia selama periode penelitian. Berdasarkan hasil perhitungan DEA, terdapat 3 bank yang mengalami efisiensi sempurna selama periode penelitian. Dari hasil uji Mann-Whitney diketahui bahwa terdapat perbedaan yang signifikan pada nilai efisiensi perbankan konvensional dan perbankan syariah di Indonesia selama triwulan pertama 2012 hingga triwulan ketiga 2013.
\end{abstract}

\section{Pendahuluan}

Perkembangan dunia perbankan di Indonesia sangat pesat setelah terjadi deregulasi di bidang keuangan, moneter dan perbankan pada paket kebijakan Juni 1983 (pakjun 1983) dan paket kebijakan oktober 1988 (pakto 1988). Deregulasi tersebut telah mengakibatkan kebutuhan dana secara langsung maupun tidak langsung melalui perbankan. Kondisi ini mendorong tumbuhnya perbankan di Indonesia, yang semakin banyak menjangkau masyarakat yang membutuhkan jasa perbankan. Berdasarkan data Bank Indonesia, jumlah bank meningkat dari 111 bank tahun 1988 menjadi 222 bank tahun 1998. Jumlah kantor bank juga meningkat dari 1.771 menjadi 7.570 pada periode yang sama.

Perkembangan perbankan di Indonesia juga ditandai dengan penghimpunan dana pihak ketiga yang meningkat mencapai Rp 357.613 Milliar tahun 1997, pertumbuhan ekspansi kredit juga mengalami peningkatan dari Rp 292.921 Miliar tahun 1996 menjadi Rp 378.134 Miliar tahun 1997. Namun permasalahan muncul pada saat sektor perbankan berkembang pesat, hal ini ditandai dengan kenaikan nilai kredit non lancar yang juga mengalami kenaikan sebesar Rp 2.845 Miliar dan nilai biaya operasional dan biaya operasional (BOPO) yang menunjukkan efisien bank juga meningkat selama periode tahun 1996-1997. Keadaan tersebut memaksa 
pemerintah untuk melikuidasi bank-bank yang dinilai tidak sehat dan tidak layak untuk beroperasi. Ditengah gejolak perekonomian bangsa saat itu, sistem perbankan syariah muncul sebagai sebuah perbankan yang mampu menunjukkan bahwa bank syariah lebih tangguh ditengah gejolak krisis moneter (Zalfan, 2011). Muharam dan Pusvitasari (2007) menjelaskan bahwa ketangguhan ini dikarenakan sistem bagi hasil yang diterapkan pada sistem perbankan syariah yang ada.

Ketangguhan perbankan syariah di Indonesia dipresentasikan oleh Bank Muammalat Indonesia (BMI). Ketika krisis moneter BMI memiliki pembiayaan bermasalah yang relatif rendah. Bahkan tercatat bahwa BMI mengalami recovery yang lebih cepat dibandingkan bank konvensional. Pada tahun 2000 kredit atau pembiayaan bermasalah bank konvensional dan bank syariah masing-masing sebesar 26,77\% dan 12,96\%. Sedangkan pada 2001, NPL bank konvensional adalah sebesar 14,08\% dan NPF dari bank syariah sebesar 4,04\%. Hal ini yang mendasari pemerintah mengeluarkan UU No 10 tahun 1998 sebagai regulasi tentang perbankan syariah. Menurut UU No. 10 tahun 1998 yang telah diamandemen oleh UU No.21 tahun 2008 kegiatan usaha perbankan Indonesia menganut dual banking system dan diakuinya bank dengan prinsip syariah, baik itu Bank Umum Syariah maupun Unit Usaha Syariah (Arif, 2012). Dengan demikian, bank umum dapat melaksanakan kegiatan usaha dengan prinsip konvensional maupun syariah, yang selanjutnya disebut sebagai bank umum konvensional dan bank umum syariah. Perbedaan mendasar dari kedua jenis perbankan tersebut terletak pada pengembalian dan pembagian keuntungan yang diberikan oleh nasabah kepada lembaga keuangan dan/atau lembaga keuangan kepada nasabah (Muhammad, 2005). Pada perbankan konvensional pembagian keuntungannya didasarkan pada prinsip bunga, sementara perbankan syariah pembagian keuntungan maupun kerugiannya didasarkan pada prinsip bagi hasil.

Efisiensi perbankan dapat ditinjau dari sudut pandang mikro maupun makro. secara mikro, bank harus beroperasi dan semakin berkembang secara efisien dalam persaingan perbankan yang semakin ketat. Hal ini karena ketidakmampuan bank dalam persaingan dapat membuat bank keluar dari pasar, baik itu dalam persaingan harga maupun kualitas produk dan pelayanan. Disamping itu bank akan kesulitan dalam mempertahankan kesetiaan nasabahnya dan tidak diminati oleh calon nasabah untuk memperbesar pasarnya (Abidin, 2007). Menurut Weill (2003), ditinjau dari sisi makro, industri perbankan yang efisien dapat mempengaruhi biaya intermediasi keuangan dan stabilitas sistem keuangan secara keseluruhan. Hal ini disebabkan oleh peran strategis perbankan sebagai lembaga intermediary dan produsen jasa-jasa keuangan. Dalam tingkat efisiensi yang tinggi, kinerja efisiensi perbankan akan semakin baik dalam mengalokasikan sumber daya keuangan dan memperlancar proses transmisi kebijakan moneter, sehingga kebijakan moneter lebih efektif mencapai sasaran. Dengan demikian dapat meningkatkan kegiatan investasi dan pertumbuhan ekonomi guna mencapai tujuan ekonomi yang diharapkan.

Rasio BOPO merupakan rasio yang mencerminkan tingkat efisiensi bank, baik untuk bank syariah maupun bank konvensional (Sandi, 2011). Nilai rasio BOPO perbankan Indonesia mengalami penurunan dari 85,3\% pada 2011 menjadi 75,4\% pada 2012 yang mengindikasikan adanya peningkatan efisiensi (Outlook Perbankan Indonesia, 2013). Sementara nilai ideal rasio BOPO menurut surat edaran Bank Indonesia 2004 adalah sebesar $50 \%-75 \%$.

Pada keadaan seperti ini penilaian efisiensi bank menjadi penting mengingat efisiensi merupakan gambaran kinerja suatu bank. Disamping itu agar input yang digunakan oleh perbankan bisa seminimal mungkin, dan output yang dihasilkan bisa maksimal, sehingga bank dapat mencapai efisiensi. Selain itu juga sekaligus menjadi faktor yang harus diperhatikan bank untuk bertindhak secara rasional dalam meminimumkan tingkat resiko perbankan dalam kegiatan operasinya. Oleh karena itu, penelitian ini bertujuan untuk mengetahui efisiensi perbankan konvensional dan perbankan syariah serta membandingkan tingkat efisiensi keduanya.

\section{Perbandingan Bank Konvensional dan Bank Syariah}

Persamaan mendasar dari bank syariah dan bank konvensional adalah sama-sama merupakan lembaga intermediasi keuangan. Antonio (2001) menjelaskan bahwa pada sisi teknis bank syariah dan bank konvensional memiliki beberapa persamaan, yakni dalam teknis penerimaan uang, mekanisme transfer, teknologi komputer yang digunakan, syarat-syarat umum yang digunakan dalam pembiayaan dan sebagainya. Sedangkan Rivai dan Arifin (2010) menyatakan bahwa Bank Syariah dan Bank Konvensional merupakan organisasi yang sama-sama bertujuan mencari keuntungan, hanya saja, pada Bank Syariah melarang adanya riba atau aktivitas bisnis yang tidak sesuai dengan prinsip syariah.

Herijanto (2013) berpendapat bahwa perbedaan antara bank syariah dan bank konvensional terletak pada filosofi atau ajarannya. Hamidi (2012) dan Rivai dkk (2012) menyebutkan beberapa faktor mendasar yang dilarang dalam sebuah lembaga keuangan syariah termasuk dalam perbankan syariah, yakni, larangan adanya riba, ketidakjelasan (gharar) dan judi (maysir). 
Senada dengan Herijanto (2013) dan Rivai dkk (2012), Machmud dan Rukmana (2010) menyatakan bahwa perbedaan pokok sistem bank syariah dan bank konvensional dapat dilihat dari beberapa aspek, pertama, aspek falsafah, dimana bank syariah tidak berdasarkan bunga dan ketidakjelasan, pada bank konvensional terdapat bunga. Kedua, aspek operasional, pada bank syariah dana yang terkumpul merupakan titipan yang akan menghasilkan apabila diusahakan dan hanya di salurkan pada sektor yang halal. Ketiga, aspek sosial dinyatakan secara tegas pada visi dan misi perbankan syariah. Keempat, aspek organisasi bank syariah memiliki Dewan Pengawas Syariah. Secara garis besar Antonio (2001) dan Machmud dan Rukmana (2010) menyatakan perbandingan bank syariah dan bank konvensional dapat dilihat pada tabel berikut:

Tabel 1. Perbandingan Bank Syariah dan Bank Konvensional

\begin{tabular}{|c|c|c|}
\hline Aspek & Bank Syariah & Bank Konvensional \\
\hline Legalitas & Akad syariah & Akad konvensional \\
\hline Struktur Organisasi & $\begin{array}{l}\text { Penghimpunan dan penyaluran dana harus } \\
\text { sesuai dengan fatwa dewan Pengawas Syariah }\end{array}$ & Tidak terdapat dewan sejenis \\
\hline \multirow{4}{*}{$\begin{array}{l}\text { Bisnis dan Usaha yang } \\
\text { dibiayai }\end{array}$} & 1. Hanya melakukan investasi yang halal & Investasi halal dan haram \\
\hline & $\begin{array}{l}\text { 2. Hubungan dengan nasabah dalam bentuk } \\
\text { kemitraan }\end{array}$ & $\begin{array}{l}\text { Hubungan dengan nasabah sebagi } \\
\text { debitur dan kreditur }\end{array}$ \\
\hline & $\begin{array}{l}\text { 3. Berdasarkan prinsip bagi hasil, jual beli, } \\
\text { atau sewa }\end{array}$ & Memakai perangkat bunga \\
\hline & $\begin{array}{l}\text { 4. Profit oriented, kemakmuran dan } \\
\text { kebahagiaan dunia akhirat }\end{array}$ & \\
\hline Lingkungan Kerja & Islami & Non Islami \\
\hline
\end{tabular}

Sumber: Antonio (2001) dan Machmud dan Rukmana (2010)

\section{Efisiensi Perbankan}

Perbankan sebagai lembaga intermediasi keuangan memiliki peran penting dalam perekonomian suatu negara. Oleh karena itu, bank dituntut untuk memiliki kinerja yang sehat/baik. Indikator kinerja yang baik tersebut salah satunya dapat dilihat dari tingkat efisiensi yang dicapai oleh bank. Dimana ukuran kinerja yang diharapkan salah satunya adalah kemampuan menghasilkan output yang maksimal dengan penggunaan input tertentu. Rose dan Hudgins (2008), menjelaskan bahwa efisiensi perbankan dapat didekomposisi menjadi efisiensi skala (scale efficiency) dan efisiensi cakupan (scope efficiency). Bank dikatakan telah mencapai efisiensi skala ketika bank bersangkutan mampu beroperasi dalam skala hasil yang konstan (constant return to scale). Sementara itu, efisiensi cakupan tercapai pada saat bank mampu beroperasi pada diversifikasi alokasi.

Muharram dan Pusvitasari (2007) melengkapi penjelasan Rose dan Hudgins (2008) dengan menambah efisiensi teknis (technical efficiency), dan efisiensi alokasi (allocative efficiency) dalam efisiensi perbankan. Bank dikatakan mencapai efisiensi alokasi pada saat bank mampu menentukan output yang dapat menghasilkan kuntungan maksimal. Sedangkan, efisiensi teknis menyatakan hubungan antara input dan output dalam suatu proses produksi. Menurut Machmud dan Rukmana (2010) suatu proses produksi dikatakan efisien apabila pada penggunaan input tertentu dapat menghasilkan output yang maksimal, atau untuk menghasilkan output tertentu dengan menggunakan input yang paling minimal. Sementara itu, Taswan (2010) menyatakan efisiensi perbankan mengandung dua dimensi yaitu tersedianya berbagai macam instrumen finansial bagi pemilik aktiva yang menguntungkan, memberikan portofolio yang paling optimal untuk kepentingan return, risk, dan likuiditas. Seperti halnya dalam setiap kegiatan ekonomi yang diharapkan dapat menciptakan barang dan jasa dengan biaya yang paling rendah yang mungkin bisa dicapai, serta mampu mengalokasikan sumber-sumber ekonomi pada penggunaan yang paling bernilai. Pada sisi sumber dana perbankan seharusnya dialokasikan pada penempatan dana yang paling bernilai.

\section{Pengukuran Efisiensi}

Muharram dan Pusvitasari (2007), menjelaskan bahwa dalam pengukuran efisiensi dapat dilakukan dengan tiga pendekatan, yaitu pendekatan rasio, pendekatan regresi, dan pendekatan frontier. Pendekatan frontier untuk mengukur efisiensi dibagi menjadi pendekatan frontier parametrik dan pendekatan frontier non parametrik. Dimana untuk mendefinisikan hubungan input dan output dalam kegiatan finansial suatu lembaga keuangan menggunakan pendekatan asset, pendekatan produksi dan pendekatan intermediasi. Pendekatan frontier parametrik adalah pengukuran efisiensi yang modelnya menetapkan adanya syarat-syarat tertentu tentang parameter populasi yang merupakan sumber penelitiannya. Pendekatan frontier parametrik biasanya diukur menggunakan metode Stochastic Frontier Analysis (SFA) dan Distribution Free Analysis (DFA) Hadad (2003). 
Pendekatan frontier non-parametrik merupakan pengukuran efisiensi yang modelnya tidak menetapkan syaratsyarat mengenai parameter populasi yang merupakan induk sampel penelitiannya. Pendekatan ini dapat diukur dengan menggunakan metode Data Envelopment Analysis (DEA) Hadad (2003).

Penelitian tentang efisiensi perbankan telah dilakukan oleh beberapa peneliti, baik di dalam maupun di luar negeri. Hasil penelitianpun berbeda-beda. Perbedaan ini disebabkan oleh penggunaan beberapa faktor yang memang berbeda diantaranya metode pengukuran, variabel input dan output, obyek penelitian dan tahun pengamatannya. Penelitian yang dilakukan oleh Mohamed Khaled I. Bader, Shamser Mohamad, Mohamed Arief dan Taufiq Hassan (2008) diketahui bahwa tidak ada perbedaan efisiensi antara bank syariah dan bank konvensional. Dari penelitian Jill Johnes, Marwan Izzeldin dan Vasileios Pappas (2010) dapat diketahui bahwa bank syariah lebih efisien dibandingkan bank konvensional. Selain itu, penelitian Haseeb Shahid, Ramiz Ur Rehman, Ghulam shabbir Khan Niazi, Awais Raoof (2010) mendapatkan bahwa efisiensi teknis bank konvensional lebih efisien dibanding bank syariah.

\section{Metode Penelitian}

Penelitian ini menggunakan 3 variabel input dan 2 variabel output. Berikut definisi operasional dari variabel yang dipakai dalam penelitian ini:

Variabel Input dalam penelitian ini adalah simpanan. Simpanan merupakan titipan murni dari nasabah baik itu perorangan maupun lembaga atau perusahaan kepada bank melalui produk penghimpunan dana baik itu berbentuk giro, tabungan maupun simpanan berjangka, dengan satuan juta rupiah. Variabel input yang kedua adalah aset. Aset adalah jumlah aset tetap yang dimiliki oleh bank baik itu bank syariah maupun bank konvensional dan memiliki manfaat ekonomis, dalam satuan juta rupiah. Dan selanjutnya biaya operasional yang merupakan biaya-biaya yang digunakan untuk kegiatan operasional bank. Biaya tersebut tidak termasuk biaya bunga pada perbankan konvensional dan biaya bagi hasil pada perbankan syariah yang diukur dalam juta rupiah.

Variabel Output: Total kredit/pembiayaan merupakan produk pinjaman/kredit berupa mata uang rupiah dan dalam bentuk valas, sedangkan pembiayaan merupakan bentuk penyaluran dana perbankan syariah dengan menggunakan akad-akad muamalah dalam satuan juta rupiah dan Laba operasional adalah pendapatan yang merupakan hasil dari kegiatan operasional perbankan yang diperoleh dari selisih antara pendapatan operasioanal dengan beban operasional dalam satuan juta rupiah.

Populasi dalam penelitian ini adalah bank umum konvensional dan bank umum syariah yang terdaftar di Bank Indonesia pada periode 2012-2013. Karena keterbatasan penulis maka, Bank Perkreditan Rakyat (BPR) dan Bank Pembangunan Daerah (BPD) tidak dimasukkan dalam penelitian ini. Dengan demikian, populasi yang digunakan adalah sejumlah 94 bank yang meliputi bank umum konvensional dan bank umum syariah dari kelompok bank persero, bank asing, bank campuran, bank devisa dan bank non devisa.

Pengambilan sampel dalam penelitian ini dilakukan dengan rumus Slovin, yaitu:

$n=\frac{N}{1+N \alpha^{2}}$

Keterangan:

$\mathrm{n} \quad=$ Jumlah sampel

$\mathrm{N} \quad=$ Populasi

$\alpha \quad=$ Taraf Signifikansi

Dari rumus tersebut, dengan taraf signifikansi sebesar $10 \%$ maka didapat sampel yang akan digunakan dalam penelitian ini adalah sejumlah:

$n=\frac{94}{1+\left(94 \times\left(0,10^{2}\right)\right.}=48,45361=49$ Bank

\section{Metode Analisis Data}

Menurut Cooper et al (2006) dan Cook dan Zhu (2007), DEA dapat digunakan untuk mengukur efisiensi secara relatif suatu unit pembuat keputusan (UPK)/Decision Making Unit (DMU), baik itu perusahaan, pemerintah maupun lembaga non-profit oriented yang dalam proses produksi atau aktivitasnya melibatkan penggunaan input tertentu untuk menghasilkan output tertentu. Masih menurut Cooper et al (2006) dan Cook dan Zhu (2007), bahwa DEA dapat digunakan pada berbagai bidang, seperti kesehatan, pendidikan, transportasi, pabrik maupun perbankan. 


\section{Data Envelopment Analisys}

DEA didesain khusus untuk menghitung efisiensi teknis untuk semua unit dengan skor efisiensi untuk setiap unit adalah relatif, tergantung pada tingkat efisiensi dari unit-unit lainnya di dalam sampel (Hadad, 2003). Dalam DEA, efisiensi relatif DMU didefinisikan sebagai rasio dari total output tertimbang dibagi total input tertimbangnya (total weightedoutput/total weighted input) (Muharram dan Pusvitasari, 2007). Setiap DMU diasumsikan bebas menentukan bobot setiap variabel input dan output yang ada asalkan memenuhi dua kondisisi yang menjadi persyaratan, yaitu: bobot tidak boleh negatif dan bobot harus bersifat universal.

Suatu unit kegiatan ekonomi dikatakan efisien secara relatif apabila setiap unit dalam sampel dianggap memiliki efisiensi yang tidak negatif, dan memiliki nilai antara 0 hingga 1, dimana nilai 1 menunjukkan efisiensi yang sempurna, namun apabila memiliki nilai kurang dari 1 menunjukkan inefisiensi.

Pendekatan DEA berorientasi pada evaluasi dari kinerja DMU, yang dilakukan melalui analisis berdasarkan evaluasi terhadap nilai efisiensi relatif DMU yang sebanding (Cooper et al, 2006). Selanjutnya DMU-DMU yang efisien tersebut akan membentuk garis frontier. Apabila DMU berada pada garis frontier, DMU tersebut dapat dikatakan efisien relatif dibandingkan dengan DMU yang lain dalam sampel.

Masih menurut Cooper et al (2006), selain menghasilkan nilai efisiensi masing-masing DMU, DEA juga dapat mengidentifikasi sumber-sumber dan jumlah yang menyebabkan inefisiensi dari variabel input dan output untuk setiap DMU. DEA juga menunjukkan unit-unit yang dapat menjadi referensi bagi unit-unit yang tidak efisien.

Menurut Cooper et al (2006) dan Zhu dan Cook (2007), terdapat dua model yang sering digunakan dalam pendekatan DEA, yaitu:

a. Charnes-Cooper-Rhodes (CCR) (1978)

Model ini mengasumsikan adanya Constant Return to Scale (CRS). Beberapa program linier ditransformasikan ke dalam program ordinary linier secara primal atau dual dengan rumus sebagai berikut:

Maksimumkan $\boldsymbol{h}_{\boldsymbol{s}}=\sum_{\boldsymbol{i}=\mathbf{1}}^{\boldsymbol{m}} \boldsymbol{U}_{\boldsymbol{i}} \boldsymbol{Y}_{\boldsymbol{t}}$

Fungsi batasan atau kendala:

$\sum_{i=1}^{m} u_{i} y_{i r}-\sum_{j=1}^{n} v_{j} x_{j r} \leq 0 ; r=1, \ldots, N$

$\sum_{j=1}^{m} v_{j} x_{j s}=1$ dimanau $_{i} \operatorname{danv}_{j} \geq 0$

$\mathrm{X}_{\mathrm{jr}}$ adalah banyaknya input tipe ke-j dari DMU ke-r dan $\mathrm{y}_{\mathrm{ir}}$ adalah jumlah output tipe ke i dari DMU ke-r. Nilai efisiensi selalu kurang atau sama dengan 1. DMU yang nilai efisiennya kurang dari 1 berarti mengalami inefisiensi, sedangkan DMU yang memiliki nilai efisiensinya sama dengan 1 berarti DMU tersebut efisien.

b. Banker-Charnes-Cooper (BCC) (1985)

Model ini mengasumsikan adanya Variabel Return to Scale (VRS), dimana peningkatan iput dan output tidak berproporsi sama. Prosporsi perubahan dapat bersifat peningkatan atau penurunan. Rumus VRS dapat dituliskan dengan program matematika sebagai berikut:

Maksimumkan $h_{s}=\sum_{i=1}^{m} u_{i} Y_{t s}-\mathrm{u}_{\mathrm{s}}$

Fungsi batasan atau kendala:

$\sum_{i=1}^{m} u_{i} y_{i r}-\sum_{j=1}^{n} v_{j} x_{j r}-u_{s} \leq 0 ; r=1, \ldots, N$

$\sum_{j=1}^{m} v_{j} x_{j s}=1$ dimanau $_{i}$ danv $_{j} \geq 0$

$\mathrm{X}_{\mathrm{jr}}$ adalah banyaknya input tipe ke-j dari DMU ke-r dan $\mathrm{y}_{\mathrm{ir}}$ adalah jumlah output tipe ke i dari DMU ke-r. Nilai efisiensi selalu kurang atau sama dengan 1. DMU yang nilai efisiennya kurang dari 1 berarti mengalami inefisiensi, sedangkan DMU yang memiliki nilai efisiensinya sama dengan 1 berarti DMU tersebut efisien.

\section{Uji Mann Whitney}

Uji Mann-Whitney merupakan salah satu uji non parametrik, yang dapat digunakan untuk mengetahui apakah terdapat perbedaan dari dua populasi data yang independen. Menurut Santoso (2012), uji Mann Whitney merupakan alternatif uji t dan uji z untuk variabel independen, hanya berjumlah 2 sampel dan keduanya tidak berhubungan satu sama lain. Sugiyono (2012), menjelaskan rumus Uji Mann-Whitney adalah sebagai berikut;

$U_{1}=n_{1} n_{2}+\frac{n_{1}\left(n_{1}+1\right)}{2}-R_{1}$

Atau

$U_{2}=n_{1} n_{2}+\frac{n_{1}\left(n_{1}+1\right)}{2}-R_{1}$

Keterangan

N1 = Jumlah sample 1

N2 = Jumlah sample 2

$\mathrm{U} 1$ = Jumlah peringkat 1 
$\mathrm{U} 2$ = Jumlah peringkat 2

$\mathrm{R} 1=$ Jumlah rangking pada sampel $\mathrm{n} 1$

$\mathrm{R} 2=$ Jumlah rangking pada sampel n2

Menurut Priyatno (2012), langkah menyusun uji Mann Whitney terdiri dari tiga langkah yaitu menyusun dan menentukan hipotesis, menentukan kriteria pengujian dan membuat kesimpulan. Hipotesis yang digunakan dalam penelitian ini adalah

$\mathrm{H}_{\mathrm{o}}=$ Tidak terdapat perbedaan tingkat efisiensi antara bank syariah dan bank konvensional.

$\mathrm{H}_{1}=$ Terdapat perbedaan efisiensi antara bank syariah dan bank konvensional.

Sementara kriteria pengujiannya apabila nilai signifikansi (Asym Sig 2-tailed) kurang dari $\alpha$ dimana $\alpha$ yang digunakan adalah 0,05 maka Ho ditolak dengan kesimpulan terdapat perbedaan efisiensi antara bank syariah dengan bank konvensional. Sebaliknya apabila nilai signifikansi lebih besar dari 0,05 maka Ho diterima dengan kesimpulan tidak terdapat perbedaan tingkat efisiensi antara bank syariah dan bank konvensional.

\section{Hasil Penelitian}

\section{Analisis Efisiensi Bank Berdasarkan Perhitungan DEA}

Berdasarkan hasil perhitungan menggunakan metode DEA dengan asumsi Constant Return to Scale (CRS). Tingkat efisiensi masing-masing perbankan pada triwulan pertama 2012 hingga triwulan ketiga 2013 dapat dilihat pada tabel 3 .

Secara keseluruhan, dari triwulan pertama 2012 hingga triwulan ketiga 2013 dapat dilihat bahwa terdapat tiga bank yang selalu mengalami efisiensi yaitu Bank of China Limited, Bank Woori Indonesia dan Standard Chartered Bank. Sementara bank yang mengalami fluktuasi pada nilai efisiensi terdapat 6 bank yaitu Maybank Syariah, Bank Chinatrust Indonesia, JP Morgan Chase Bank N.A, Bank Mestika Dharma, Rabobank Internasional Indonesia, dan The Royal Bank of Scotland. Selain itu, bank dalam sampel mengalami inefisiensi sepanjang periode penelitian.

Metode DEA selain digunakan untuk mengukur nilai efisiensi bank juga memberikan referensi atau acuan bank bagi bank-bank yang belum mencapai efisien agar mampu mencapai kondisi yang efisien. Terdapat sembilan bank yang pernah mengalami efisiensi selama triwulan penelitian. Bank tersebut yaitu Maybank Syariah, Bank Of China Limited, Bank Woori Indonesia, Bank Chinatrust Indonesia, JP Morgan Chase Bank NV, Bank Mestika Dharma, Rabobank Internasional Indonesia, The Royal Bank of Scotland dan Standard Chartered Bank. Bank Of China Limited, Bank Woori Indonesia dan Standard Chartered Bank yang mengalami efisiensi sempurna sepanjang periode penelitian digunakan sebagai referensi bank yang belum mengalami efisiensi secara berurutan masing-masing sebanyak 215 kali, 102 kali dan 54 kali. Sementara itu, Maybank Syariah yang mengalami efisiensi sebanyak 6 kali selama periode penelitian dijadikan referensi bagi bank-bank yang inefisien sebanyak 24 kali dalam periode penelitian. Selanjutnya, Bank Chinatrust Indonesia dan Bank Mestika Dharma yang mengalami efisiensi sebanyak 5 kali pada periode penelitian digunakan sebagai referensi bank yang inefisien masing-masing sebanyak 151 kali dan 28 kali selama periode penelitian. Selain itu, JP Morgan Chase Bank NA yang mengalami efisiensi sempurna sebanyak 3 kali dan The Royal Bank Of Scotland yang telah mengalami efisiensi sebanyak 2 kali selama periode penelitian digunakan sebagai acuan bank sebanyak 64 kali dan 43 kali. Bank Rabobank Internasional yang hanya mengalami sekali efisiensi sepanjang periode penelitian digunakan sebagai referensi sebanyak 36 kali sepanjang periode penelitian.

Dari 49 bank yang menjadi obyek penelitian, menunjukkan bahwa terdapat tiga bank yang mengalami efisiensi sempurna selama periode penelitian. Dengan demikian keseluruhan bank dapat dikatakan belum efisien. Mayoritas penyebab inefisiensi pada setiap unit kegiatan ekonomi (dalam penelitian ini Bank) adalah penggunaan variabel input baik itu simpanan, aset dan biaya operasional yang melebihi target penggunaan agar tercapai efisiensi sempurna. Dengan permasalahan ini agar bank dapat efisien maka, sebaiknya bank-bank yang inefisien mengurangi penggunaan input yang ada pada nilai radial movement. Meskipun dengan sejumlah nilai pada radial movement bank sudah efisien namun sebenarnya bank masih dapat mencapai nilai efisien dengan mengurangi nilai yang ada pada nilai slack movement. Pengurangan dapat dilakukan misalnya dengan mengubah input simpanan menjadi aset lancar atau pada penggunaan input biaya operasional dapat dikurangi dengan memangkas biaya-biaya yang dirasa kurang begitu penting.

Penyebab mayoritas kedua yang mengakibatkan bank mengalami inefisiensi adalah ketidakmampuan bank dalam menghasilkan output sesuai target. Kurang maksimalnya output yang dihasilkan oleh setiap bank seringkali terjadi hanya pada salah satu output yaitu kredit/pembiayaan saja atau laba operasional saja. Kurang maksimalnya kredit/pembiayaan dapat diatasi dengan memaksimalkan fungsi intermediasi bank yaitu dengan menambah variasi produk kredit/pembiayaan. Hal ini juga didasari oleh fakta bahwa di beberapa bank yang inefisien hampir seluruhnya memiliki kelebihan dalam penggunaan input simpanan. Dengan demikian 
masyarakat berminat untuk melakukan kredit/pembiayaan. Selanjutnya dari kredit/pembiayaan tadi bank dapat menghasilkan laba operasional. Sehingga laba juga akan meningkat.

Tabel 3. Tingkat Efisiensi 49 Bank Umum di Indonesia (Persen)

\begin{tabular}{|c|c|c|c|c|c|c|c|}
\hline \multirow{3}{*}{ Nama Bank } & \multicolumn{7}{|c|}{ Tahun (triwulan) } \\
\hline & \multicolumn{4}{|c|}{2012} & \multicolumn{3}{|c|}{2013} \\
\hline & 1 & 2 & 3 & 4 & 1 & 2 & 3 \\
\hline Bank Central Asia Syariah & 16,10 & 24,30 & 33,80 & 32,40 & 36,80 & 34,20 & 33,80 \\
\hline Bank Jabar Banten & 34,20 & 32,40 & 35,00 & 29,70 & 31,20 & 27,60 & 28,50 \\
\hline Bank Muammalat Indonesia & 32,90 & 42,80 & 45,60 & 40,80 & 43,10 & 42,20 & 42,30 \\
\hline Bank Negara Indonesia Syariah & 17,20 & 17,30 & 25,50 & 27,90 & 26,50 & 30,20 & 30,20 \\
\hline Bank Rakyat Indonesia Syariah & 10,90 & 18,10 & 20,70 & 18,60 & 22,50 & 20,80 & 24,40 \\
\hline Bank Syariah Mandiri & 28,40 & 35,20 & 40,50 & 30,50 & 45,90 & 31,20 & 30,40 \\
\hline Bank Syariah Bukopin & 18,90 & 23,70 & 26,90 & 53,10 & 24,70 & 23,00 & 22,20 \\
\hline Maybank Syariah & 57,20 & 100,00 & 100,00 & 100,00 & 100,00 & 100,00 & 100,00 \\
\hline Bank Mega Syariah & 22,10 & 40,20 & 44,80 & 45,70 & 35,80 & 47,50 & 40,00 \\
\hline Panin Syariah & 44,50 & 62,60 & 70,90 & 53,10 & 65,60 & 44,00 & 41,00 \\
\hline Victoria Syariah & 7,10 & 12,60 & 10,50 & 14,70 & 17,90 & 20,60 & 20,80 \\
\hline Bank Agris & 32,90 & 44,40 & 62,00 & 73,20 & 82,10 & 50,00 & 45,70 \\
\hline OCBC NISP & 55,60 & 71,30 & 76,50 & 74,30 & 75,10 & 66,90 & 62,70 \\
\hline Bank Anz & 63,30 & 83,10 & 52,60 & 79,00 & 83,80 & 73,90 & 70,60 \\
\hline Centratama Nasional Bank & 45,20 & 65,70 & 59,50 & 66,10 & 73,80 & 65,20 & 60,50 \\
\hline Bank Central Asia Konvensional & 46,40 & 57,50 & 64,90 & 64,10 & 61,90 & 56,80 & 60,00 \\
\hline Bank Capital Indonesia & 36,30 & 43,50 & 50,60 & 53,00 & 50,60 & 43,80 & 43,90 \\
\hline Bank of China Limited & 100,00 & 100,00 & 100,00 & 100,00 & 100,00 & 100,00 & 100,00 \\
\hline Bank Commonwealth & 33,70 & 64,50 & 59,70 & 65,90 & 68,10 & 72,60 & 65,10 \\
\hline Bank Internasional Indonesia & 53,40 & 69,40 & 71,40 & 73,50 & 68,00 & 57,80 & 56,30 \\
\hline Bank Bisnis Internasional & 67,10 & 85,10 & 87,60 & 88,40 & 97,60 & 77,40 & 74,70 \\
\hline Bank Mandiri Konvensional & 61,40 & 69,40 & 78,60 & 65,80 & 71,70 & 63,60 & 67,70 \\
\hline Bank Negara Indonesia Konvensional & 53,40 & 60,70 & 68,00 & 64,20 & 69,50 & 63,30 & 65,00 \\
\hline Bank Royal Indonesia & 30,10 & 42,80 & 55,10 & 66,60 & 59,80 & 50,60 & 63,10 \\
\hline BRI Agroniaga & 43,50 & 59,90 & 70,90 & 70,00 & 72,30 & 64,20 & 63,40 \\
\hline Bank Rakyat Indonesia Konvensional & 68,20 & 76,00 & 84,70 & 81,30 & 82,90 & 80,40 & 75,90 \\
\hline Bank Tabungan Negara & 60,50 & 82,60 & 86,60 & 82,80 & 81,30 & 75,20 & 69,60 \\
\hline Bank Tabungan Pensiunan Nasional & 67,10 & 72,00 & 81,60 & 72,30 & 80,70 & 77,60 & 85,30 \\
\hline Bank Bukopin Konvensional & 50,50 & 74,40 & 67,30 & 71,60 & 64,40 & 54,00 & 56,70 \\
\hline Bank Woori Indonesia & 100,00 & 100,00 & 100,00 & 100,00 & 100,00 & 100,00 & 100,00 \\
\hline CIMB Niaga & 65,00 & 78,60 & 80,70 & 77,50 & 71,40 & 70,40 & 65,50 \\
\hline Citibank N,A & 65,70 & 61,40 & 67,10 & 60,80 & 59,20 & 54,70 & 68,30 \\
\hline Bank Chinatrust Indonesia & 81,20 & 100,00 & 100,00 & 97,90 & 100,00 & 100,00 & 100,00 \\
\hline Bank Danamon Indonesia & 55,70 & 80,60 & 85,90 & 80,90 & 84,00 & 78,90 & 70,50 \\
\hline Bank Dinar Indonesia & 55,70 & 74,60 & 85,50 & 83,40 & 75,10 & 63,60 & 66,30 \\
\hline JP Morgan Chase Bank N,A & 100,00 & 100,00 & 86,30 & 100,00 & 79,80 & 49,90 & 72,30 \\
\hline Bank Kesejahteraan Ekonomi & 64,40 & 72,40 & 74,80 & 76,20 & 76,70 & 74,10 & 66,20 \\
\hline Bank Mayapada Internasional & 59,80 & 67,40 & 72,70 & 69,40 & 72,50 & 61,90 & 60,70 \\
\hline Bank Mega Konvensional & 53,00 & 54,70 & 56,00 & 43,60 & 50,60 & 39,30 & 39,40 \\
\hline Bank Mestika Dharma & 94,50 & 100,00 & 100,00 & 98,70 & 100,00 & 100,00 & 100,00 \\
\hline Bank Permata & 57,00 & 73,70 & 77,30 & 77,00 & 73,60 & 61,80 & 60,90 \\
\hline Prima Master Bank & 52,60 & 72,80 & 72,10 & 83,10 & 80,30 & 69,10 & 66,20 \\
\hline Bank Pundi Indonesia & 28,70 & 62,80 & 63,50 & 60,40 & 64,00 & 55,30 & 54,90 \\
\hline Bank Rabobank Internasional Indonesia & 100,00 & 80,50 & 83,60 & 88,10 & 80,60 & 69,80 & 70,10 \\
\hline The Royal Bank of Scotland N,V & 32,10 & 64,00 & 77,90 & 100,00 & 74,70 & 74,30 & 100,00 \\
\hline Standard Chartered Bank & 100,00 & 100,00 & 100,00 & 100,00 & 100,00 & 100,00 & 100,00 \\
\hline Bank Sinarmas & 41,20 & 61,80 & 59,40 & 63,00 & 63,50 & 55,80 & 49,00 \\
\hline Bank UOB Indonesia (duluUOB Buana) & 65,20 & 73,60 & 78,20 & 80,80 & 76,00 & 67,00 & 62,30 \\
\hline Bank Victoria Internasional & 84,90 & 73,00 & 74,00 & 77,90 & 86,80 & 91,30 & 76,10 \\
\hline Pencapaian Rata-Rata Efisiensi Bank & 53,36 & 64,97 & 67,89 & 68,92 & 68,62 & 62,28 & 62,21 \\
\hline Rata-rata efisiensi perbankan & & & & 64,04 & & & \\
\hline
\end{tabular}

Sumber: Data Publikasi Bank, Diolah 


\section{Perbandingan Tingkat Efisiensi Perbankan Konvensional Dan Perbankan Syariah Di Indonesia}

Penelitian ini menggunakan Uji Mann Whitney dengan menggunakan program SPSS 19 untuk menganalisis ada dan tidaknya perbedaan antara kelompok bank konvensional dan kelompok bank syariah di Indonesia. Dari hasil olah data diketahui untuk kelompok 1 (Bank Syariah) menghasilkan nilai rata-rata untuk kelompok bank syariah sebesar 65,17 dan untuk kelompok 2 (Bank Konvensional) menghasilkan nilai rata-rata 197,45. Besar nilai Mann Whitney yang diperoleh adalah 2090 dan nilai signifikansinya yaitu 0,000 .

Dari hasil tersebut diketahui bahwa nilai signifikansinya $0,000<0,05$. Sehingga Ho ditolak. Dengan demikian dapat disimpulkan bahwa terdapat perbedaan tingkat efisiensi antara bank syariah dan bank konvensional di Indonesia. Pada hipotesis Ho tidak terdapat perbedaan tingkat efisiensi antara bank syariah dan bank konvensional dan Ha terdapat perbedaan tingkat efisiensi antara bank syariah dan bank konvensional.

Tabel 4. Hasil Uji Beda Mann Whitney

\begin{tabular}{lccc}
\hline \multicolumn{1}{c}{ Kelompok } & Mean Rank & Nilai Mann Whitney & Nilai Signifikansi \\
\hline Bank Syariah & 65,17 & 2090 & 0,000 \\
Bank Konvensional & 197,45 & & \\
\hline
\end{tabular}

Sumber: Hasil Olah Data

\section{Simpulan}

Berdasarkan dari hasil analisis yang telah dilakukan pada pada bab sebelumnya, maka dapat ditarik kesimpulan sebagai berikut:

1. Dari 49 bank yang terdiri dari 11 bank syariah dan 38 bank konvensional yang menjadi sampel pada penelitian ini, diketahui bahwa terdapat tiga bank yang mengalami efisiensi 100 persen secara terus menerus pada triwulan 1-2012 hingga triwulan 3-2013. Bank tersebut termasuk kategori bank konvensional yaitu Bank Of China Limited, Bank Woori Indonesia, dan Standard Chartered Bank. Sedangkan 35 bank konvensional yang lain mengalami efisiensi yang fluktuatif, yaitu Bank Agris, OCBC NISP, Bank Anz, Centratama Nasional Bank, Bank Central Asia Konvensional, Bank Capital Indonesia, Bank Commonwealth, Bank Internasional Indonesia, Bank Bisnis Internasional, Bank Mandiri Konvensional, Bank Negara Indonesia Konvensional, Bank Royal Indonesia, BRI Agroniaga, Bank Rakyat Indonesia Konvensional, Bank Tabungan Negara, Bank Tabungan Pensiunan Nasional, Bank Bukopin Konvensional, CIMB Niaga, Citibank N.A, Bank Chinatrust Indonesia, Bank Danamon Indonesia, Bank Dinar Indonesia, JP Morgan Chase Bank NA, Bank Kesejahteraan Ekonomi, Bank Mayapada Internasional, Bank Mega Konvensional, Bank Mestika Dharma, Bank Permata, Prima Master Bank, Bank Pundi Indonesia, Rabobank Internasional Indonesia, The Royal Bank Of Scotland NV, Bank Sinarmas, Bank UOB Indonesia, dan Bank Victoria Internasional. Secara umum, penyebab inefisiensi pada bank-bank tersebut dikarenakan oleh pengaruh variabel input dan output yang dimiliki oleh bank berbeda terhadap nilai efisiensi yang dicapai oleh bank. Ketidakefisienan yang terjadi pada bank-bank yang inefisien dapat disebabkan oleh penggunaan input baik itu simpanan, aset dan biaya operasional. Mayoritas bank-bank yang inefisien menggunakan input yang berlebihan dibandingkan target yang seharusnya digunakan untuk mencapai efisiensinya. Selain itu, pada beberapa bank juga menghasilkan output yang kurang maksimal. Hal ini dikarenakan output yang dihasilkan belum mencapai target yang diharapkan. Kedua kondisi ini merupakan penyebab bank-bank mengalami inefisiensi pada periode penelitian ini.

2. Satu-satunya bank syariah yang pernah mengalami efisiensi 100 persen pada periode penelitian adalah Maybank Syariah. Maybank Syariah mengalami efisiensi sebanyak 6 kali dari total periode penelitian sebanyak 7 kali. Hal ini sekaligus menunjukkan bahwa 10 bank syariah lain dari total sampel 11 bank umum syariah dan unit usaha syariah belum efisien. 10 bank yang belum pernah mengalami efisiensi selama periode penelitian tersebut adalah Bank Central Asia Syariah, Bank Jabar Banten, Bank Muammalat Indonesia, Bank Negara Indonesia Syariah, Bank Rakyat Indonesia Syariah, Bank Syariah Mandiri, Bank Syariah Bukopin, Bank Mega Syariah, Panin Syariah dan Victoria Syariah. Ketidakefisienan pada bank-bank tersebut sebagian besar disebabkan oleh variabel input yaitu simpanan, aset dan biaya operasional. Hal ini menandakan bahwa telah terjadi penggunaan input yang berlebihan dibandingkan target penggunaan input yang diharapkan. Disisi lain, output yang dihasilkan belum maksimal karena belum sesuai dengan target agar bank beroperasi secara efisien. Keadaan tersebut terjadi pada bank-bank yang mengalami inefisiensi pada periode penelitian ini.

3. Dari hasil perhitungan menggunakan metode DEA menunjukkan bahwa selama triwulan 1-2012 hingga triwulan 3-2013 perbankan di Indonesia mengalami inefisiensi yang fluktuatif. Perhitungan uji MannWhitney menujukkan rata-rata efisiensi sebesar 65,17 persen untuk bank syariah dan 197,45 untuk bank 
konvensional. Dari hasil uji beda Mann-Whitney dapat diambil kesimpulan pula bahwa terdapat perbedaan tingkat efisiensi antara bank konvensional dan bank syariah selama periode triwulan 1-2012 hingga triwulan 3-2013 dengan melihat nilai signifikansi Mann-Whitney dibandingkan probabilitas $\alpha$ yang diperoleh dari uji Mann-Whitney.

\section{Daftar Pustaka}

Zalfan, Muhammad. 2011. Seminar Perbankan Syariah. Disampaikan dalam Seminar Nasional Perbankan Syariah di FEB UMS.

Muharam, Harjum dan Pusvitasari. 2007. Analisis Perbandingan Efisiensi Bank Syariah di Indonesia dengan Metode Data Envelopment Analysis. Jurnal Ekonomi dan Bisnis Islam. Vol.2 No.3 Hal: 80-116.

Rivai dkk. 2008. Identifikasi Faktor Penentu Keputusan Konsumen dalam Memilih Jasa Perbankan: Bank Syariah VS Bank Konvensional. Penelitian Kerjasama Bank Indonesia dan Center for Banking Research Universitas Andalas. www.bi.go.id. Diakses, Jum'at 22 November 2013.

Rianto Al Arif, M. Nur. 2012. Lembaga Keuangan Syariah Suatu Kajian Teoritis Praktis. Bandung: CV Pustaka Setia.

Abidin, Zaenal. 2007. Kinerja Efisiensi Pada Bank Umum.Proceeding PESAT Vol. 2. Auditorium Kampus Gunadharma. 21-22 Agustus 2007.

Abidin, Zaenal dan Endri. 2009. Kinerja Efisiensi Teknis Bank Pembangunan Daerah: Pendekatan Data Envelopment Analysis (DEA). Jurnal Akuntansi dan Keuangan. Vol.11 No.1 Hal:21-29.

Antonio, Muhammad Syafi'i. 2001. Bank syariah dari Teori Ke Praktik. Jakarta: Gema Insani Press.

Rivai, Veithzal dan Arviyan Arifin. 2010. Islamic Banking: Sebuah Teori, Konsep, dan Aplikasi. Jakarta: Bumi Aksara.

Bank Indonesia. 2004. Surat Edaran Bank Indonesia No.6/ 23 /DPNP. http://www.bi.go.id. Diakses Kamis, 14 November 2013.

Bank Indonesia. 2013. Direktori Bank Indonesia. http://www.bi.go.id. Diakses Rabu, 30 Oktober 2013.

Bank indonesia. 2013. Laporan Keuangan Publikasi Bank. http://www.bi.go.id. Diakses Desember 2013.

Bank Indonesia. 2013. Laporan Tahunan Bank Indonesia tahun 1997/1998.http://www.bi.go.id. Diakses Sabtu, 14 September 2013.

Bank Indonesia. 2013. Statistik Perbankan Indonesia. http://www.bi.go.id. Diakses Selasa, 17 September 2013.

Bank Indonesia. 2013. Statistik Perbankan Syariah. http://www.bi.go.id. Diakses Rabu, 18 September 2013.

Rivai, Veithzal dkk. 2012. Islamic Banking and Finance Dari Teori ke Praktik bank dan Keuangan Syariah Sebagai Solusi dan Bukan Alternatif. Yogyakarta: BPFE.

Machmud, Amir dan Rukmana. 2010. Bank Syariah Teori, Kebijakan, dan Studi Empiris di Indonesia. Jakarta: Erlangga.

Rose, Peter S dan Sylvia C. Hudgins. 2008. Bank Management and Financial Services Seventh Edition. New York: Mc Graw Hill.

Taswan. 2010. Manajemen Perbankan: Konsep, Teknik, dan Aplikasi. Yogyakarta: UPP STIM YKPN.

Hadad, Muliaman D dkk. 2003. Analisis Efisiensi Industri Perbankan Indonesia: Penggunaan Metode Non Parametrik Data Envelopment Analysis (DEA). Buletin Ekonomi Moneter dan Perbankan. http://www.bi.go.id. Diakses Sabtu, 21 September 2013.

Johnes, Jill dkk. 2010. Efficiency in Islamic and conventional banks: A comparison based on financial ratios and data envelopment analysis. Journal of Lancaster University. www.lums.lancs.ac.uk. Diakses Senin, 23 September 2013.

Bader, Mohamad Khaled I. 2008. Cost, Revenue, and Profit Efficiency of Islamic versus Conventional Banks: International Evidence Using Data Envelopment Analysis (DEA). Journal of Islamic Economic Studies. Vol.15, No.2, Hal. 23-76. 
Cooper, William W dkk. 2006. Introduction To Data Envelopment Analysis And Its Uses With DEA-Solver Software And References. http://www.libgen.org. Diakses Senin, 30 Desember 2013.

Zhu, Joe dan Wade D. Cook. 2007. Modelling Data Irregularities and Structural Complexities in Data Envelopment Analysis. http://www.libgen.org. Diakses Senin, 30 Desember 2013.

Santoso, Singgih. 2012. Panduan Lengkap SPSS Versi 20. Jakarta: PT Elex Media Komputindo.

Sugiyono, 2012. Statistika untuk Penelitian. Bandung: Alfabeta.

Priyatno, Duwi. 2012. Belajar Cepat Olah Data dengan SPSS. Yogyakarta: Andi Offset.

Wardana, Sandi Kusuma dan Djumahir. 2011. “Analisis Tingkat Efisiensi Perbankan Dengan Pendekatan Non Parametrik Data Envelopment Analysis (DEA) (Studi Pada Bank Umum di Indonesia Tahun 20052011). Jurnal Ilmiah Mahasiswa FEB. Universitas Brawijaya.

Herijanto, Hendy. 2013. Selamatkan Perbankan Demi Perekonomian Indonesia!. Bandung: Mizan Publika.

Pemerintah Indonesia. 2008. Undang-Undang Republik Indonesia No. 21 Tahun 2008 Tentang Perbankan Syariah. http://bi.go.id. Diakses Selasa, 24 September 2013.

Tarmidi, Lepi T. 1999. Krisis Moneter Indonesia: Sebab, Dampak, Peran IMF dan Saran. Buletin Ekonomi Moneter dan Perbankan. Edisi Maret 1999. 